\title{
Development of low-cost culture media for Ankistrodesmus gracilis based on inorganic fertilizer and macrophyte
}

\author{
Desenvolvimento de meios de cultura de baixo custo para Ankistrodesmus gracilis à base \\ de fertilizante inorgânico e macrófita
}

\author{
Lúcia Helena Sipaúba-Tavares ${ }^{1 *}$, Alexandra Maria Donadon Lusser Segali ${ }^{1}$, \\ Flavia Almeida Berchielli-Morais ${ }^{1}$ and Bruno Scardoeli-Truzzi ${ }^{1}$
}

\begin{abstract}
${ }^{1}$ Laboratório de Limnologia e Produção de Plâncton, Centro de Aquicultura, Universidade Estadual Paulista - UNESP, Via de Acesso Prof. Paulo Donato Castellane, s/n, CEP 14884-900, Jaboticabal, SP, Brazil

*e-mail:sipauba@caunesp.unesp.br
\end{abstract}

Cite as: Sipaúba-Tavares, L.H. et al. Development of low-cost culture media for Ankistrodesmus gracilis based on inorganic fertilizer and macrophyte. Acta Limnologica Brasiliensia, 2017, vol. 29 , e5.

\begin{abstract}
Aim: The influence of three different culture media on the growth and biochemical composition of Ankistrodemsus gracilis microalgae is evaluated. Methods: Microalgae were placed in a bath culture during 28 days, with inorganic fertilizer (NPK) and macrophyte Eichhornia crassipes as culture medium to compare the growth of microalgae and commercial medium $\mathrm{CHU}_{12}$. Protein and lipid contents, water conditions of the culture medium and physiological parameters were assessed weekly. Results: Growth rate, macro-minerals, micro-nutrients and nutritional values were similar to commercial culture medium in the media with inorganic fertilizer and macrophyte. The biological indexes of microalgae were not influenced by weekly differences during the study period. Although lipid contents, nitrogen and growth rate of $A$. gracilis were higher in inorganic fertilizer and macrophyte media; Mn, B, Cu, S, dry matter, ash content, cell volume, TOC and total length were similar among the media used. The same high cell density $25 \times 10^{5}$ cells. $\mathrm{mL}^{-1}$ was obtained in NPK and in $\mathrm{CHU}_{12}$ medium respectively after 11 and 14 days cultivation. Conclusion: Culture media inorganic fertilizer (NPK) and macrophyte (Eichhornia crassipes), were adequate and may replace the commercial medium $\mathrm{CHU}_{12}$ for the cultivation of microalgae $A$. gracilis, resulting in high nutritional composition, high biomass, high nutrients and low-cost.
\end{abstract}

Keywords: Eichhornia crassipes; NPK (20-5-20); biochemical composition; culture media.

Resumo: Objetivos: Este estudo avaliou a influência de três diferentes meios de cultura para o crescimento e composição bioquímica da microalga Ankistrodesmus gracilis. Métodos: A microalga foi cultivada em sistema estático durante 28 dias utilizando o fertilizante inorgânico (NPK) e a macrófita Eichhornia crassipes como meio de cultura, comparando o desempenho desta microalga com o meio comercial $\mathrm{CHU}_{12}$. Os teores de proteína e lipídios, condiçóes da água do meio de cultura e variáveis fisiológicas foram avaliados semanalmente. Resultados: Os meios com fertilizante inorgânico e com macrófita apresentaram condiçôes de crescimento e valor nutricional similar ao meio de cultura comercial. Os índices biológicos da microalga náo foram influenciados por diferenças semanais durante o período do estudo. O teor de lipídio, nitrogênio e a taxa de crescimento de $A$. gracilis foram superiores no meio com fertilizante inorgânico e com macrófitas. Já o teor de $\mathrm{Mn}, \mathrm{B}, \mathrm{Cu}, \mathrm{S}$, massa seca, teores de cinzas, o volume celular, TOC e comprimento total foram semelhantes nos meios utilizados. As maiores densidades celulares de $25 \times 10^{5}$ células. $\mathrm{mL}^{-1}$ foram obtidas no meio NPK com 11 dias de cultivo e no meio $\mathrm{CHU}_{12}$ com 14 dias de cultivo. Conclusáo: Os meios de cultura 
com fertilizante inorgânico (NPK) e com macrófita (Eichhornia crassipes) foram adequados e podem substituir o meio comercial $\mathrm{CHU}_{12}$ para o cultivo da microalga $A$. gracilis tendo como resultados elevados valores nutricionais, elevada biomassa, altos teores de nutrientes com baixo custo.

Palavras-chave: Eichhornia crassipes; NPK (20-5-20); composiçâo bioquimíca; meio de cultura.

\section{Introduction}

Several studies on microalgae biology have been recently undertaken with microorganisms as a protein source, mainly in the aquaculture industry, as feed for fish larvae or with by-products such as lipids, carbohydrates, vitamins, minerals and pigmentation (keto-carotenoid astaxanthin). The cultivation of microalgae as prime feed for fish larvae is currently regarded as essential in aquaculture study albeit expensive as a live food source. A possible solution to minimize the, high costs of microalgae cultivation is the use of an alternative medium to obtain microalgae biomass, which is essential as live food for fish larvae. The production of microalgae is a high economical investment due to the high costs of the culture medium to obtain microalgae biomass.

Strategies such as alternative media should be undertaken to decrease costs without affecting the nutritional values of microalgae. Successful attempts have been made to substitute commercial media for alternative, less expensive ones. For instance, an inorganic fertilizer is feasible since it is widely available, it dissolves easily, it has a well-defined composition, or rather high nitrogen and phosphorus contents, and triggers moderate $\mathrm{pH}$ in the medium (Tew et al., 2006). Microalgae grow in an inorganic fertilizer (NPK, 20-5-20) which has a similar or greater effect on the growth of microalgae than commercial medium (Ashraf et al., 2011; Brito et al., 2013; Sipaúba-Tavares et al., 2011). Some authors have indicated that the agricultural fertilizer media were eight times cheaper than conventional medium (Ashraf et al., 2011; El-Nabris, 2012; Brito et al., 2013).

Another alternative medium for the growing of microalgae consists of a mixture of macrophytes (Eichhornia crassipes) and inorganic fertilizers (NPK). In fact, the aquatic plant has a high concentration of nitrogen and phosphorus and other nutrients which are important for the growth of microalgae at low costs (Sipaúba-Tavares et al., 2009).

The concentration of nitrogen and phosphorus in culture media has a fundamental and direct influence on microalgae growth, besides being closely related to lipid accumulation (Lee et al.,
2013). Growth rate, cell density and lipid contents of microalgae directly contribute towards the biological indexes of the microorganisms (Huang et al., 2013). Increase in lipid accumulation is related to an increase in iron concentration in the medium. Liu et al. (2008) observed that Chlorella vulgaris showed high lipid accumulation when there were high iron concentrations in the medium. However, other important micronutrients, such as boron, copper, zinc and manganese albeit in smaller amounts, are required, for the growth of microalgae (Larsdotter, 2006).

Culture medium conditions such as temperature, light, $\mathrm{pH}$ and nutrients, affect not only photosynthesis and productivity of microalgae cells but also influence the activity of cell metabolism and its composition (Huang et al., 2013).

Microalgae, such as Ankistrodesmus gracilis, have been used in aquaculture due to their rapid growth rate, resistance to adverse conditions, nutritional quality and also as model organism for the analysis of cell growth and division. Detailed knowledge on microalgae culture in alternative media and at low costs for the cultivation of $A$. gracilis may be efficient at least in batch culture mode to improve physiological difference more than the commercial media. Current assay investigates weekly biological performance of Ankistrodesmus gracilis for a low-cost culture media based on the use of an inorganic fertilizer (NPK) and macrophyte (Eichhornia crassipes).

\section{Methods}

\subsection{Microalgae cultures and laboratory conditions}

Current study on $A$. gracilis comprised three trials namely, microalgae cultivated in alternative media, NPK (20-5-20), macrophyte with NPK $(\mathrm{M}+\mathrm{NPK})$, and in pure commercial medium $\left(\mathrm{CHU}_{12}\right)$ as control, and cells grown in batch culture. The $A$. gracilis strain used in current study was obtained from culture collection number $005 \mathrm{CH}$, originally from Broa Reservoir $\left(22^{\circ} 15^{\prime} \mathrm{S}\right.$ and $47^{\circ} 19^{\prime}$ W), Brazil. Algae were batch cultured at $22 \pm 2{ }^{\circ} \mathrm{C}$ and, exposed to light at $40 \mu \mathrm{mol} \cdot \mathrm{m}^{-2} \cdot \mathrm{s}^{-1}$, while culture parameters were measured weekly during the 28 day experiment. The growth of A. gracilis involved inorganic fertilizer NPK 
medium (20-5-20) (Sipaúba-Tavares \& Rocha, 1993), commercial $\mathrm{CHU}_{12}$ medium and medium with a mixture of macrophyte (Eichhornia crassipes) extract and NPK (20-5-20) (Sipaúba-Tavares et al., 2009). The mixture contained approximately $5 \mathrm{~kg}$ of Eichhornia crassipes, which was ground and boiled in distilled water for one hour. The hot extract was filtered and autoclaved at $120{ }^{\circ} \mathrm{C}$, during 20 minutes. After autoclaving, a sample $(70 \mathrm{~mL})$ was collected and, after cooling it was diluted with distilled water up to 1.4-L when $2.5 \mathrm{~mL}$ NPK were added (Sipaúba-Tavares et al., 2009). The experiment started with $250 \mathrm{~mL}$ flasks, with microalgae density of $2 \times 10^{5}$ cells. $\mathrm{mL}^{-1}$ and cultured in NPK medium. When cultures reached the late exponential growth phase (7 day), about $200 \mathrm{~mL}$ of culture density $\left(0.7 \times 10^{5}\right.$ cells. $\left.\mathrm{mL}^{-1}\right)$ were added in 2-L flasks with NPK medium. After a 7 day exponential growth phase, the culture was transferred to sterilized recipients containing 13-L at density $4.4 \times 10^{5}$ cells. $\mathrm{mL}^{-1}$ of NPK medium; $5.1 \times 10^{5}$ cells. $\mathrm{mL}^{-1}$ of macrophyte with NPK medium $(\mathrm{M}+\mathrm{NPK})$; and $4.4 \times 10^{5}$ cells. $\mathrm{mL}^{-1}$ of $\mathrm{CHU}_{12}$ medium. The experiments were performed in 13-L volumes with continuous air bubbling. Vitamin $B_{12}$ complex was added to NPK and macrophyte with NPK medium at the rate of 0.02 g. $\mathrm{L}^{-1}$ plus biotin $\left(0.01 \mathrm{mg} . \mathrm{L}^{-1}\right)$ (Table 1$)$. Growth performance and other physiological parameters and analytical method were analysed weekly $(1,7,14,21,28$ days) during the study period.

\subsection{Growth performance}

Triplicate $1 \mathrm{~mL}$ aliquots were removed daily from the microalgae culture and a minimum of $2 \times 1 \mu \mathrm{L}$ sub-samples were used for cell quantification by a Neubauer hemocytometer. Growth rate $(\mathrm{k})$ was calculated by the formula: $\mathrm{k}=\left(3.322 / \mathrm{t}_{2}-\mathrm{t}_{1} \times \log \mathrm{N}_{2} / \mathrm{N}_{1}\right)(\mathrm{t}=$ time; $\mathrm{N}=$ number of cells; subscripts denote values at different times) (Guillard, 1973). Division per day was calculated by formula: Div.day ${ }^{-1}=K / \ln _{2}$ (Foggs \& Thake, 1987). Doubling time (cell division time or generation time) was calculated from results obtained from growth rate, by the formula: $\mathrm{Td}=1 \mathrm{k}^{-1}(\mathrm{Td}=$ duplication time, $1 \mathrm{k}^{-1}=$ days per division) (Guillard, 1973). Dry biomass and ash content were determined following Vollenweider (1974). Total length of 50 specimens was determined with microscope Leica DFC 295 by image analysis system LAS core (LAS V3.8), with a $40 \mathrm{X}$ micrometric objective. Cell volume was calculated by mean cell size with the use of the most appropriate geometric form, or rather the sphere formula (Hillebrand et al., 1999). Total organic carbon (TOC) was calculated by $\mathrm{C}=0.1204 . \mathrm{V}^{1.051}$ ( $\mathrm{C}=$ carbon content in pg.cell ${ }^{-1} ; \mathrm{V}=$ cell volume $)$ using regression according to Rocha \& Duncan (1985).

\subsection{Microalgae biomass and parameters of culture media}

The physical and chemical parameters of the culture media and microalgae biomass were performed weekly. Dissolved oxygen, $\mathrm{pH}$ and conductivity of culture media were measured with multiparametric probe YSI 556 MPS. Total ammonia nitrogen (TAN) was quantified with a spectrophotometer according to Koroleff (1976) and total phosphorus was quantified as described by Golterman et al. (1978). Chlorophyll-a, concentration was determined by colorimetric analysis using spectrophotometer after extraction with 90\% ethanol (Nusch, 1980). The biomass of microalgae was harvested, centrifuged, and lyophilized for the analysis of proteins, lipids (AOAC, 1990) and macro-minerals (N, P, K, Ca, $\mathrm{Mg}$ and $\mathrm{S})$ and micro-nutrients $(\mathrm{B}, \mathrm{Cu}, \mathrm{Fe}, \mathrm{Mn}$, and

Table 1. Composition of nutrients (g.L $\left.\mathrm{L}^{-1}\right)$ of different culture media: NPK; Macrophyte with NPK $(\mathrm{M}+\mathrm{NPK})$ and $\mathrm{CHU}_{12}$.

\begin{tabular}{lccc}
\hline \multirow{2}{*}{ Ingredients } & \multicolumn{3}{c}{ Medium } \\
\cline { 2 - 4 } & NPK & M+NPK & CHU $_{12}$ \\
\hline $\mathrm{P}_{2} \mathrm{O}_{5}$ & 2.5 & - & - \\
$\mathrm{K}_{2} \mathrm{O}$ & 10 & - & - \\
$\mathrm{N}$ & 10 & 0.095 & - \\
$\mathrm{P}$ & - & 0.091 & - \\
$\mathrm{C}$ & - & 0.199 & - \\
$\mathrm{Mn}$ & - & 0.06 & - \\
$\mathrm{Mg}$ & - & 0.003 & - \\
$\mathrm{Fe}$ & - & 2.18 & - \\
$\mathrm{K}$ & - & 0.056 & - \\
$\mathrm{Ca}$ & - & 0.001 & - \\
$\mathrm{Cu}(\mathrm{mg})$ & - & 0.05 & - \\
$\mathrm{Thiamine}$ & 0.007 & 0.007 & - \\
$\mathrm{Vit} \mathrm{B}_{2}$ & 0.007 & 0.007 & - \\
$\mathrm{Vit} \mathrm{B}_{6}$ & 0.005 & 0.005 & - \\
$\mathrm{Vit} \mathrm{B}_{12}\left(\mu \mathrm{Hg} . \mathrm{L}^{-1}\right)$ & 33 & 33 & - \\
$\mathrm{Biotin}\left(\mathrm{mg}_{\mathrm{L}} \mathrm{L}^{-1}\right)$ & 0.01 & 0.01 & - \\
$\mathrm{Ca}\left(\mathrm{NO}_{3}\right)_{2}$ & - & - & 3.0 \\
$\mathrm{Na}_{2} \mathrm{CO}_{3}$ & - & - & 2.0 \\
$\mathrm{KCl}_{\mathrm{K}}$ & - & - & 0.5 \\
$\mathrm{SiO}_{2}$ & - & - & 0.5 \\
$\mathrm{MgSO}_{4} 7 \mathrm{H}_{2} \mathrm{O}$ & - & - & 7.5 \\
$\mathrm{~K}_{2} \mathrm{HPO}_{4}$ & - & - & 0.5 \\
$\mathrm{FeCl}_{3 .} 6 \mathrm{H}_{2} \mathrm{O}$ & - & - & 0.5 \\
\hline & & & \\
\hline
\end{tabular}


$\mathrm{Zn)}$ of microalgae biomass was performed according to the methods describe by Bataglia et al. (1983).

\subsection{Analysis of cost culture medium}

The costs of culture media components include the prices of vitamin B complex, NPK fertilizer and different raw materials for commercial medium $\left(\mathrm{CHU}_{12}\right)$. The costs analysed for a 2 - $\mathrm{L}$ producing $100,000 \mathrm{~L}$ month $^{-1}$ (g. $\mathrm{L}^{-1}$ dry mass) of culture medium.

\subsection{Data analysis}

All data were subjected to one-way analysis of variance (ANOVA) with Statistica 8.0, to test the effects of the medium. Differences were significant at $\mathrm{p}<0.05$. All results were expressed as means $\pm S D$ (Standard Deviation). Statistical analyses were performed with Statistica 8.0 (STATSOFT, 2007) and experiments were carried out in triplicate, except protein and lipid that were done once a week.

\section{Results}

After the 28 day experimental period, the weekly performance of $A$. gracilis microalgae revealed that cell growth was different during the $\log$ phase (1-11 days for NPK; 1-14 days for $\mathrm{M}+\mathrm{NPK}$; $1-15$ days for $\mathrm{CHU}_{12}$ ). The highest cell density was observed for the NPK medium (11-days) and commercial medium $\mathrm{CHU}_{12}$ (14-days) with $25.5 \times 10^{5}$ cells.mL $\mathrm{m}^{-1}$ and $\mathrm{M}+\mathrm{NPK}$ medium (13-days) with $24.2 \times 10^{5}$ cells. $\mathrm{mL}^{-1}$. Ankistrodesmus gracilis microalga grown on $\mathrm{CHU}_{12}$ medium showed lower cell density during senescent phase (16-28 days), ranging between 12.1 and 22.3 cells. $\mathrm{mL}^{-1}$. In NPK medium, density was highest during the log phase (1-11 days) that ranged between 5.4 and 25.5 cells. $\mathrm{mL}^{-1}$. Ankistrodesmus gracilis microalga cell density decreased in all media from the $13^{\text {th }}$ day $\left(\mathrm{M}+\mathrm{NPK}\right.$ and NPK) and $15^{\text {th }}$ day $\left(\mathrm{CHU}_{12}\right)$. Ankistrodesmus. gracilis microalga cell density in the three culture media varied between $4.3 \times 10^{5}$ cells. $\mathrm{mL}^{-1}$ and $25.6 \times 10^{5}$ cells. $\mathrm{mL}^{-1}$ in $\mathrm{CHU}_{12}$ medium; between $3.2 \times 10^{5}$ cells. $\mathrm{mL}^{-1}$ and $24.2 \times 10^{5}$ cells. $\mathrm{mL}^{-1}$ in $\mathrm{M}+\mathrm{NPK}$ medium and between $5.4 \times 10^{5}$ cells. $\mathrm{mL}^{-1}$ and $25.5 \times 10^{5}$ cells. $\mathrm{mL}^{-1}$ in NPK medium (Figure 1).

The growth rate $(\mathrm{k}=0.24)$ and division day (0.35 div. day ${ }^{-1}$ ) were higher in M+NPK medium. Chlorophyll- $a$ and doubling time were higher $(\mathrm{p}<0.01)$ in $\mathrm{CHU}_{12}$ medium. Cell volume, dry biomass, total length, ash content and TOC were similar $(\mathrm{p}>0.05)$ in the culture media. Ankistrodesmus gracilis microalgae in inorganic fertilizer and macrophyte culture media showed higher biological indexes such as growth rate and division per day (Table 2). Microalgae protein content ranged between $27 \%$ and $48 \%$ of total algal dry weight and lipids contents below $14 \%$ of dry weight. As a rule, protein and lipid contents

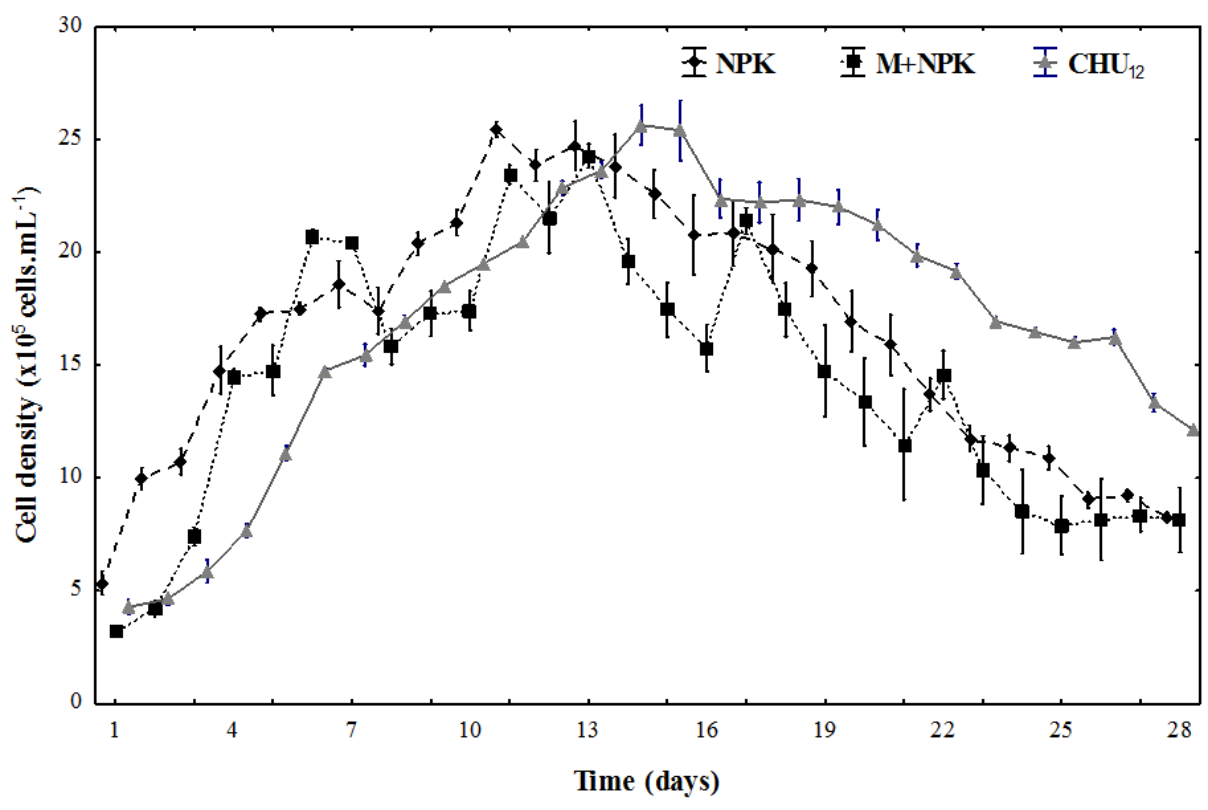

Figure 1. Growth of Ankistrodesmus gracilis in three different media: inorganic fertilizer (NPK), macrophyte with inorganic fertilizer $(\mathrm{M}+\mathrm{NPK})$ and commercial $\left(\mathrm{CHU}_{12}\right)$. Data represent mean $\pm \mathrm{SD}$ of three replicates per medium (NPK, M+NPK and $\mathrm{CHU}_{12}$ ). 
were higher in NPK and M+NPK media than in commercial medium (Table 2).

Lower dissolved oxygen concentrations (5.0-5.5 mg.L $\left.\mathrm{L}^{-1}\right)$ and conductivity $\left(320-470 \mu \mathrm{S} . \mathrm{cm}^{-1}\right)$ were registered in $\mathrm{M}+\mathrm{NPK}$ medium, but higher $\mathrm{pH}$ (7.9-10) occurred in $\mathrm{CHU}_{12}$ and $\mathrm{M}+\mathrm{NPK}$ culture media. Decrease in total ammonia nitrogen and total phosphorus in $\mathrm{M}+\mathrm{NPK}$ medium on the $21^{\text {st }}$ day was observed when $\mathrm{pH} \leq 5$ a sharp protein decrease occurred (Table 2, Figures 2 and 3). Higher total phosphorus (4.1-5.0 mg. $\left.\mathrm{L}^{-1}\right)$ was obtained in NPK medium and TAN was higher in

Table 2. Parameters of Ankistrodesmus gracilis cultured in inorganic fertilizer (NPK), macrophyte with inorganic fertilizer $(\mathrm{M}+\mathrm{NPK})$ and commercial media $\left(\mathrm{CHU}_{12}\right)$. Data represent mean $\pm \mathrm{SD}^{*}$ of three replicates per medium (NPK, $\mathrm{M}+\mathrm{NPK}$ and $\mathrm{CHU}_{12}$ ).

\begin{tabular}{|c|c|c|c|}
\hline \multirow{2}{*}{ Parameters } & \multicolumn{3}{|c|}{ Medium } \\
\hline & NPK & M+NPK & $\mathrm{CHU}_{12}$ \\
\hline Chlorophyll-a (mg.L-1) & $758 \pm 217^{b}$ & $357 \pm 166^{c}$ & $1,899 \pm 821^{\mathrm{a}}$ \\
\hline Mean cell density $\left(\times 10^{5}\right.$ cell $\left.\mathrm{mL}^{-1}\right)$ & $16.2 \pm 6^{a}$ & $12.7 \pm 5^{b}$ & $16.5 \pm 6^{a}$ \\
\hline Growth rate $(k)$ & 0.22 & 0.24 & 0.19 \\
\hline Division. day ${ }^{-1}$ (div. day $\left.{ }^{-1}\right)$ & 0.32 & 0.35 & 0.32 \\
\hline Doubling time (days) & 4.47 & 4.81 & 5.04 \\
\hline Dry weight (pg. cell-1) & $5.1 \pm 3^{a}$ & $4.4 \pm 2^{a}$ & $3.5 \pm 2^{\mathrm{a}}$ \\
\hline Ash (\% dry biomass) & $1.5 \pm 0.3^{a}$ & $2.7 \pm 1.7^{\mathrm{a}}$ & $1.7 \pm 0.6^{a}$ \\
\hline Protein (\% dry biomass) & $41.3 \pm 3.4^{\mathrm{a}}$ & $37.7 \pm 7.6^{\mathrm{a}}$ & $31.8 \pm 4.8^{\mathrm{b}}$ \\
\hline Lipid (\% dry biomass) & $12.3 \pm 0.8^{a}$ & $9.9 \pm 1.3^{b}$ & $2.8 \pm 1.4^{c}$ \\
\hline Total lenght $(\mu \mathrm{m})$ & $14.2 \pm 1^{\mathrm{a}}$ & $14.7 \pm 1^{\mathrm{a}}$ & $13.4 \pm 1^{\mathrm{a}}$ \\
\hline Cell volume $\left(\mu \mathrm{m}^{3}\right)$ & $65.7 \pm 16.2^{\mathrm{a}}$ & $71.2 \pm 20.1^{a}$ & $59.8 \pm 11.2^{\mathrm{a}}$ \\
\hline TOC (pg.cell $\left.{ }^{-1}\right)$ & $9.9 \pm 2^{\mathrm{a}}$ & $10.8 \pm 3^{a}$ & $8.9 \pm 2^{\mathrm{a}}$ \\
\hline Conductivity $\left(\mu \mathrm{S} . \mathrm{cm}^{-1}\right)$ & $1,144 \pm 23^{a}$ & $1,125 \pm 40^{a}$ & $384 \pm 55^{b}$ \\
\hline
\end{tabular}

*In each row, means followed by the same letter do not significantly differ $(\mathrm{p}<0.05)$.
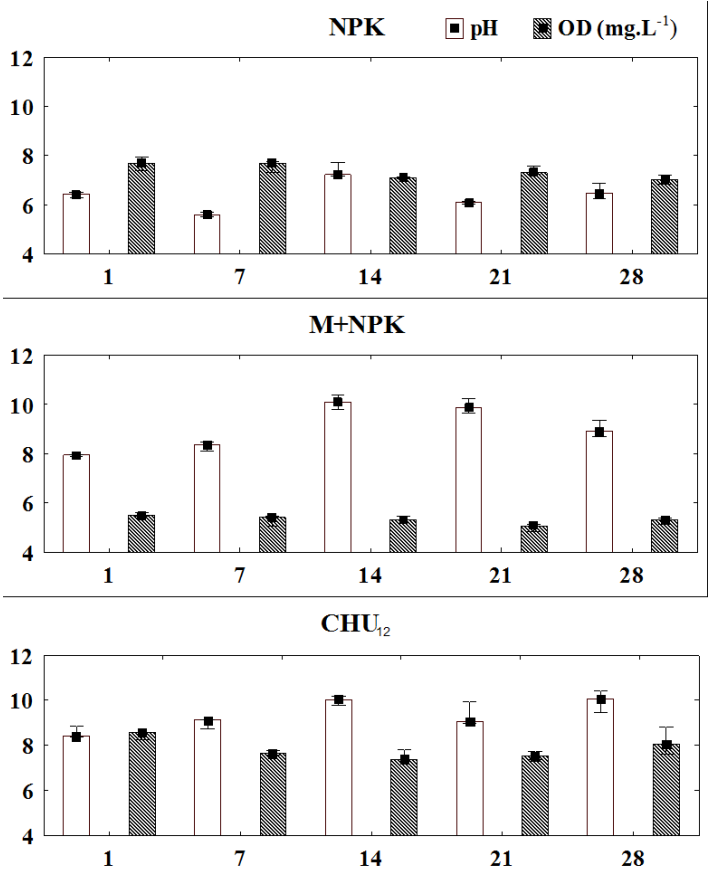

Time (days)

Figure 2. Weekly variations of $\mathrm{pH}$ and dissolved oxygen (DO) of culture media parameters from three different media: inorganic fertilizer (NPK), macrophyte with inorganic fertilizer $(\mathrm{M}+\mathrm{NPK})$ and commercial $\left(\mathrm{CHU}_{12}\right)$. Data represent mean $\pm \mathrm{SD}$ of three replicates per medium (NPK, M+NPK and $\mathrm{CHU}_{12}$ ).

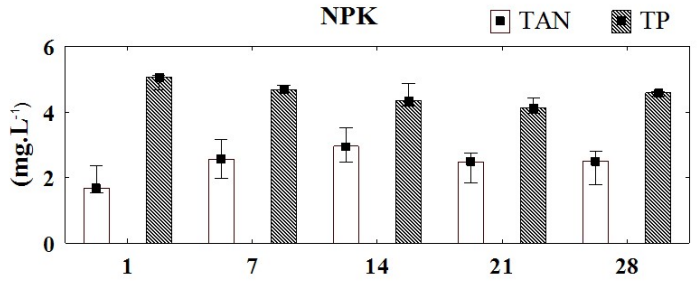

M+NPK
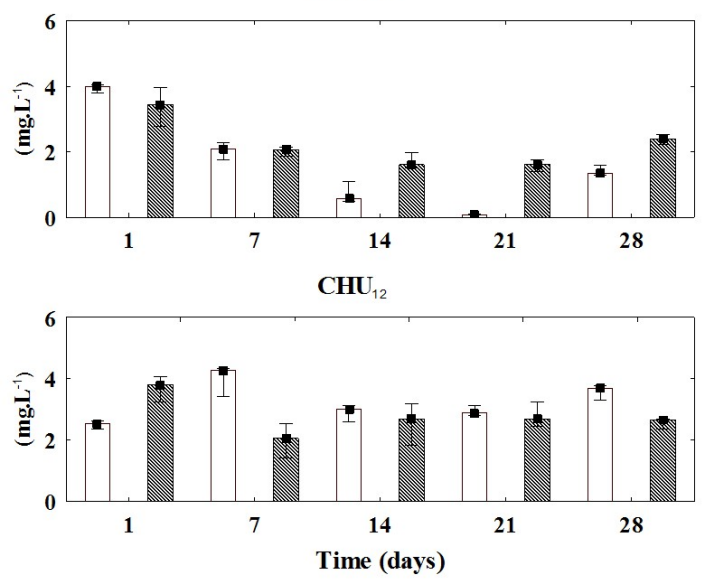

Figure 3. Weekly variations of total phosphorus (TP) and total ammonia nitrogen (TAN) of culture media parameters from three different media: inorganic fertilizer (NPK), macrophyte with inorganic fertilizer $(\mathrm{M}+\mathrm{NPK})$ and commercial $\left(\mathrm{CHU}_{12}\right)$. Data represent mean $\pm \mathrm{SD}$ of three replicates per medium (NPK, M+NPK and $\left.\mathrm{CHU}_{12}\right)$. 
$\mathrm{CHU}_{12}$ (2.9-4.0 g.. $\left.\mathrm{L}^{-1}\right)$ (Figure 3). Weekly variations $(\mathrm{p}<0.05)$ were observed in microalgae biomass of culture media parameters during the study period (28 days). Difference $(\mathrm{p}<0.05)$ was observed in total phosphorus, total ammonia nitrogen, $\mathrm{pH}$ and conductivity in the culture media (Figure 3).

Biomass of $A$. gracilis microalgae demonstrated high levels of nutrients in NPK and $\mathrm{CHU}_{12}$ media. Although the commercial medium $\mathrm{CHU}_{12}$ had all the nutrients necessary for microalgae growth, NPK and M+NPK media for $A$. gracilis microalgae biomass showed higher levels of the elements under analysis. Sulfur, B, Cu and Mn were similar ( $p>0.05)$ among the analysed minerals in the three culture media, although nitrogen was higher in inorganic fertilizer and macrophyte media. Potassium and Fe were higher in NPK medium, whilst P, C and $\mathrm{Mg}$ were higher in $\mathrm{CHU}_{12}$ medium. Although zinc was lower in M+NPK medium, the element was similar in the others culture media (Table 3). NPK and $\mathrm{M}+\mathrm{NPK}$ culture media registered a $69 \%$ and $94 \%$ cost reduction, respectively, when compared to commercial medium $\left(\mathrm{CHU}_{12}\right)$.
Estimation of yield of microalgae biomass were 3.9 g. $\mathrm{L}^{-1}$ for $\mathrm{M}+\mathrm{NPK}, 3.1 \mathrm{~g} . \mathrm{L}^{-1}$ for $\mathrm{CHU}_{12}$ and 4 g. $\mathrm{L}^{-1}$ for NPK of dry biomass of $A$. gracilis, ranged cost between US\$6,600 (M+NPK) and US\$22,200 $\left(\mathrm{CHU}_{12}\right)$, while the average cost per liter was US $\$ 0.11$ for M+NPK, US $\$ 0.57$ for NPK and US\$1.89 for $\mathrm{CHU}_{12}$ (Table 4).

\section{Discussion}

Microalgae in NPK and M+NPK culture media had a similar productive response to that reported in commercial medium. The growth rate was higher in NPK and M+NPK media than in commercial medium due to the combination of phosphorus, nitrogen and potassium contents; which always produced higher algal densities. Ashraf et al. (2011) concluded that phosphorus was one of the limiting nutrients for Chlorella vulgaris growth. According to Shilton et al. (2012), phosphorus removal in algae is due to biomass growth and phosphorus content in the macrophytes and algal biomass may be tripled from $1 \%$ to $3 \%$ via luxury uptake. In the NPK

Table 3. Values obtained for macronutrients and micronutrients (g. $\left.\mathrm{L}^{-1}\right)$ of Ankistrodesmus gracilis biomass in inorganic fertilizer (NPK), macrophyte with inorganic fertilizer $(\mathrm{M}+\mathrm{NPK})$ and commercial medium $\left(\mathrm{CHU}_{12}\right)$. Data represent mean $\pm \mathrm{SD}^{*}$ of three replicates per medium (NPK, $\mathrm{M}+\mathrm{NPK}$ and $\left.\mathrm{CHU}_{12}\right)$.

\begin{tabular}{lccc}
\hline \multirow{2}{*}{ Nutrient Composition } & \multicolumn{3}{c}{ Media } \\
\cline { 2 - 4 } & NPK & M + NPK & CHU $_{12}$ \\
\hline Boron (B) & $6 \pm 4^{\mathrm{a}}$ & $3 \pm 1^{\mathrm{a}}$ & $7 \pm 1^{\mathrm{a}}$ \\
Calcium (Ca) & $12 \pm 11^{\mathrm{b}}$ & $6 \pm 3^{\mathrm{b}}$ & $66 \pm 31^{\mathrm{a}}$ \\
Copper (Cu) & $52 \pm 20^{\mathrm{a}}$ & $25 \pm 27^{\mathrm{a}}$ & $21 \pm 16^{\mathrm{a}}$ \\
Iron (Fe) & $3,992 \pm 1844^{\mathrm{a}}$ & $1,151 \pm 1143^{\mathrm{b}}$ & $2,922 \pm 1540^{\mathrm{ab}}$ \\
Magnesium (Mg) & $3 \pm 1^{\mathrm{b}}$ & $2 \pm 1^{\mathrm{b}}$ & $28 \pm 7^{\mathrm{a}}$ \\
Manganese (Mn) & $112 \pm 9^{\mathrm{a}}$ & $54 \pm 23^{\mathrm{a}}$ & $65 \pm 23^{\mathrm{a}}$ \\
Nitrogen (N) & $60 \pm 7^{\mathrm{a}}$ & $54 \pm 4^{\mathrm{ab}}$ & $46 \pm 8^{\mathrm{b}}$ \\
Phosphorus (P) & $16 \pm 7^{\mathrm{ab}}$ & $8 \pm 2^{\mathrm{b}}$ & $22 \pm 4^{\mathrm{a}}$ \\
Potassium (K) & $9 \pm 2^{\mathrm{a}}$ & $7 \pm 1^{\mathrm{ab}}$ & $6 \pm 1^{\mathrm{b}}$ \\
Sulfur (S) & $6 \pm 1^{\mathrm{a}}$ & $4 \pm 2^{\mathrm{a}}$ & $5 \pm 1^{\mathrm{a}}$ \\
Zinc (Zn) & $75 \pm 24^{\mathrm{a}}$ & $35 \pm 17^{\mathrm{b}}$ & $67 \pm 12^{\mathrm{a}}$ \\
\hline
\end{tabular}

*In each row, means followed by the same letter do not significantly differ $(\mathrm{p}<0.05)$.

Table 4. Estimation of components cost (US\$ dollars) ${ }^{2}$ for $2-\mathrm{L}$ producing $100,000 \mathrm{~L}$ month ${ }^{1}$ (g.L $\mathrm{L}^{-1}$ dry biomass) of Ankistrodesmus gracilis in different culture media (NPK, $\mathrm{M}+\mathrm{NPK}$ and $\mathrm{CHU}_{12}$ ).

\begin{tabular}{|c|c|c|c|}
\hline \multirow{2}{*}{ Production Input } & \multicolumn{3}{|c|}{ Culture Media } \\
\hline & NPK & M+NPK & $\mathrm{CHU}_{12}$ \\
\hline \multicolumn{4}{|l|}{ Costs (US\$) } \\
\hline Cost per liter of concentrated medium & 0.57 & 0.11 & 1.85 \\
\hline Total annual costs* & 19,542 & 6,600 & 22,200 \\
\hline \multicolumn{4}{|l|}{ Production } \\
\hline Yield of one liter the concentrated culture medium $\left(\mathrm{L}^{-1}\right)$ & 35 & 20 & 100 \\
\hline Yield of microalgae biomass (g. $\mathrm{L}^{-1}$ dry biomass) & 4.0 & 3.9 & 3.1 \\
\hline Annual biomass production (tonne dry biomass) ${ }^{*}$ & 4,800 & 4,680 & 3,722 \\
\hline
\end{tabular}

${ }^{a}$ Average exchange rate (February 2017) US $\$ 1.00=\mathrm{R} \$ 3.11$; ${ }^{*}$ Estimate based on a production of 100,000 liters per month. 
medium, the phosphorus in $A$. gracilis biomass was similar to commercial medium $\left(\mathrm{CHU}_{12}\right)$.

Ankistrodesmus gracilis grown in alternative media reached cell density close to $25.5 \times 10^{5}$ cells. $\mathrm{mL}^{-1}$ in NPK medium and $24.2 \times 10^{5}$ cells. $\mathrm{mL}^{-1}$ in $\mathrm{M}+\mathrm{NPK}$ medium. These results were lower than those by Mártinez-Córdova et al. (2012) in their research on Chaetoceros muller with agricultural fertilizer, which reached $3.7 \times 10^{6}$ cells. $\mathrm{mL}^{-1}$ and higher than values by Kalita et al. (2011) which reached $9.0 \times 10^{5}$ cells. $\mathrm{mL}^{-1}$ in BG-11 medium with the same microalgae. The relative growth rate of microalgae is considerably affected by initial cell density and longer lag phase. The above factors may have influenced the growth of $A$. gracilis in $\mathrm{CHU}_{12}$ medium in current study. Secondary metabolites produced by microalgae are highly abundant in the stationary phase or in slower growing culture (Grabski \& Tukaj, 2008). The same has been reported in current analysis where nutrients and the biochemical composition of $A$. gracilis microalgae were observed in this phase with the exception of nitrogen and protein in $\mathrm{CHU}_{12}$ medium with higher levels in the senescent phase. According to Grabski \& Tukaj (2008), cell bio-volume, dry biomass content and photosynthesis demonstrated that results of growth processes of cell cycles depended on the medium. In current experiment the high density of $A$. gracilis was best in NPK and M+NPK culture media during the lag phase of growth, but the density of these microalgae after 13 days was better in the $\mathrm{CHU}_{12}$ medium.

Contents of lipids and proteins production in alternative media were somewhat higher than those obtained from microalgae in $\mathrm{CHU}_{12}$ medium. Lipid contents in current study were lower and varied from $5 \%$ in $\mathrm{CHU}_{12}$ medium to $15 \%$ in NPK medium, when compared to those by George et al. (2014) in cultures of Ankistrodesmus falcatus in BG-11 medium (67\%). According to these authors, lipid production was best under light intensity $60 \mu \mathrm{mol} . \mathrm{m}^{-2} . \mathrm{s}^{-1}$ for $A$. falcatus, whereas the microalga $A$. gracilis in current study was cultured under $40 \mu \mathrm{mol} . \mathrm{m}^{-2} \cdot \mathrm{s}^{-1}$ in all culture media. Efficient use of photons is one of the major factors that affect biomass and lipid production in microalga cultures (George et al., 2014). However, the biochemical composition of microalgae may be altered by changing the physical and chemical parameters of the culture medium (Huang et al., 2013).

Nitrogen contents in $\mathrm{CHU}_{12}$ and NPK culture media of current analysis were higher between $1 \mathrm{mg} \cdot \mathrm{L}^{-1}$ and $4 \mathrm{mg} \cdot \mathrm{L}^{-1}$. High nitrogen conditions significantly decrease the lipid fraction of many microalgae and enhance the increase of protein levels (Uslu et al., 2011). Results in current assay were similar to those obtained by these authors. Although nitrogen sources responded well and enhanced microalgae growth, Arumugam et al. (2013) reported that maximum growth was recorded for potassium nitrate, indicating favorable nitrogen source for the growth of Scenedesmus sp. In fact nitrogen and potassium are actually two important nutrients for microalgae growth.

The addition of Fe, $\mathrm{Mn}, \mathrm{Mo}$ and $\mathrm{Ni}$ in the culture medium for the growth of microalgae is extremely useful to assess the complementation to growth and lipid production (Song et al., 2012). Iron and Mn in the microalgae biomass were relevant to improve growth but not efficient to lipid accumulation, since nutrients were not high in the culture media, albeit important to fulfill the microalgae function in $\mathrm{CHU}_{12}$ and in $\mathrm{M}+\mathrm{NPK}$ media. The effect of culture medium may also be perceived on the composition of microalgae. The presence of $\mathrm{Zn}, \mathrm{Mg}, \mathrm{Fe}, \mathrm{Cu}$ and $\mathrm{B}$ are essential for photosynthesis and the metabolites of these micronutrients and are closely linked to protein synthesis and energy production (Hänsch \& Mendel, 2009).

Current study indicated higher NPK and $\mathrm{M}+\mathrm{NPK}$ media, including vitamin $\mathrm{B}_{12}$ complex, in term of money saving with commercial $\mathrm{CHU}_{12}$ medium. A great difference in price was found between $\mathrm{CHU}_{12}$ and $\mathrm{M}+\mathrm{NPK}$ media, and microalgae culture in NPK and $\mathrm{M}+\mathrm{NPK}$ media had a similar productive response to cultures in commercial medium. Annual biomass production was higher in NPK and M+NPK culture media and the cost per liter of commercial medium was higher than alternative media. Consequently, the use of inorganic fertilizer and E. crassipes with NPK may provide similar or better results at lower costs.

When all the factors mentioned above are taken into account, it may be concluded that biological indexes, growth performance and microalgae biomass were not influenced by weekly differences during the study period. Results showed that the NPK and M+NPK media was a good tool for the bath culture mode for $A$. gracilis in the laboratory. Further, protein content, lipids contents, $\mathrm{N}$, growth rate and division per day in microalgae biomass were higher in NPK and macrophyte media. However, $\mathrm{Mn}, \mathrm{B}, \mathrm{Cu}, \mathrm{S}$, dry weight, ash contents, cell volume, TOC and total length were similar for all media.

Results showed NPK and macrophyte media had similar responses to biomass and nutritional values 
and may indicate that combination of inorganic fertilizer and macrophyte supported the growth of Ankistrodesmus gracilis and confirmed adequate media to replace the commercial one $\left(\mathrm{CHU}_{12}\right)$. It would represent an alternative for culture media supplementation to $A$. gracilis to obtain a biomass with great impact from the economical point of view and feasibility. In commercial aquaculture, microalgae culture at low costs and high nutritional value are important to increase fish survival rate, mainly during the first days of live when live food is the basic feed sources.

\section{Acknowledgements}

The authors would like to thank FAPESP for financial support (12/09844-4) and CNPq. Thanks are due to the colleagues of the Limnology and Plankton Production Laboratory for their assistance in laboratory analyses.

\section{References}

Association of Official Analytical Chemists - AOAC. Official methods of analysis. 15th ed. Washington: AOAC, 1990. http://dx.doi.org/10.1590/5010384782008000600051.

ARUMUGAM, M., AGARWAL, A., ARYA, M.C. and AHMED, Z. Influence of nitrogen sources on biomass productivity of microalgae Scenedesmus bijugus. Bioresource Technology, 2013, 131(1), 246249. PMid:23353039. http://dx.doi.org/10.1016/j. biortech.2012.12.159.

ASHRAF, M., JAVAID, M., RASHID, T., AYUB, M., ZAFAR, A., ALI, S. and NAEEM, M. Replacement of expensive pure nutritive media with low cost commercial fertilizer for mass culture of freshwater algae, Chlorella vulgaris. International Journal of Agriculture and Biology, 2011, 13(4), 484.

BATAGLIA, O.C., FURLANI, A.M.C., TEIXEIRA, J.P.F., FURLANI, P.R. and GALLO, J.R. Chemical analysis methods for plants. Campinas: Instituto Agronômico, 1983, 48 p. Boletim Técnico, vol. 78.

BRITO, D., CASTRO, A., GUEVARA, M., GÓMEZ, E., RAMOS-VILLARROEL, A. and ARON, N.M. Biomass and pigments production of the mixed culture of microalgae (Hyaloraphidium contortum and Chlorella vulgaris) by cultivation in media based on commercial fertilizer. Food Technology, 2013, 37(1), 85-97.

EL-NABRIS, K.J.A. Development of cheap and simple culture medium for the microalgae Nannochloropsis sp. based on agricultural grade fertilizers available in the local market of Gaza stripe (Palestine). Journal of Al Azhar University-Gaza, 2012, 14, 61-76.
FOGGS, G.E. and THAKE, B. Algal cultures and phytoplankton ecology. Madison: The University of Wisconsin Press, 1987, 269 p.

GEORGE, B., PANCHA, I., DESAI, C., CHOKSHI, K., PALIWAL, C., GHOSH, T. and MISHRA, S. Effects of different media composition, light intensity and photoperiod on morphology and physiology of freshwater microalgae Ankistrodesmus falcatus: a potential strain for bio-fuel production. Bioresource Technology, 2014, 171(1), 367-374. PMid:25218209. http://dx.doi.org/10.1016/j.biortech.2014.08.086.

GOLTERMAN, H.L., CLYMO, R.S. and OHNSTAD, M.A.M. Methods for physical and chemical analysis of fresh water. 2nd ed. Oxford: Blackwell Scientific Publication, 1978, 213 p. IBP Handbook, vol. 8.

GRABSKI, K. and TUKAJ, Z. Auto-induction activity of a conditioned medium obtained from high density cultures of a green alga Scenedesmus subspicatus. Journal of Applied Phycology, 2008, 20(3), 323-330. http://dx.doi.org/10.1007/s10811-007-9260-x.

GUILLARD, R.R.L. Division rates. In J.R. STEIN. Handbook of phycological methods: culture methods and growth measurements. Cambridge: University Press, 1973, pp. 289-320.

HÄNSCH, R. and MENDEL, R.R. Physiology functions of mineral micronutrients $(\mathrm{Cu}, \mathrm{Zn}, \mathrm{Mn}$, $\mathrm{Fe}, \mathrm{Ni}, \mathrm{Mo}, \mathrm{B}, \mathrm{Cl})$. Current Opinion in Plant Biology, 2009, 12(3), 259-266. PMid:19524482. http:// dx.doi.org/10.1016/j.pbi.2009.05.006.

HILLEBRAND, H., DÜRSELEN, C.-D., KIRSCHTEL, D., POLLINGHER, U. and ZOHARY, T. Biovolume calculation for pelagic and benthic microalgae. Journal of Phycology, 1999, 35(2), 403-424. http://dx.doi.org/10.1046/j.15298817.1999.3520403.x.

HUANG, X., HUANG, Z., WEN, W. and YAN, J. Effects of nitrogen supplementation of the culture medium on the growth, total lipid content and fatty acid profiles of three microalgae (Tetraselmis subcordiformis, Nannochloropsis oculata and Pavlova viridis). Journal of Applied Phycology, 2013, 25(1), 129-137. http://dx.doi.org/10.1007/s10811-0129846-9.

KALITA, N., BARUAH, G., GOSWAMI, R.C.D., TALUKDAR, J. and KALITA, M.C. Ankistrodesmus falcatus: a promising candidate for lipid production, its biochemical analysis and strategies to enhance lipid productivity. Journal of Microbiology and Biotechnology Research, 2011, 1(4), 148-157.

KOROLEFF, F. Determination of ammonia. In K. GGRASSHOFF, ed. Methods of seawater analysis. German: Verlag Chemie Weinhein, 1976, pp. 126133.

LARSDOTTER, K. Wastewater treatment with microalgae: a literature review. Vatten [online], 2006, 62(1), 31-38 [viewed 31 May 2016]. Available from: www.tidkriftenvatten.se/de 
LEE, S.H., AHN, C.Y., JO, B.H., LEE, S.A., PARK, J.Y., AN, K.G. and OH, H.M. Increased microalgae growth and nutrient removal using balanced $\mathrm{N}: \mathrm{P}$ ratio in wastewater. Journal of Microbiology and Biotechnology, 2013, 23(1), 92-98. PMid:23314374. http://dx.doi.org/10.4014/jmb.1210.10033.

LIU, Z.Y., WANG, G.C. and ZHOU, B.C. Effect of iron on growth and lipid accumulation in Chlorella vulgaris. Bioresource Technology, 2008, 99(11), 47174722. PMid:17993270. http://dx.doi.org/10.1016/j. biortech.2007.09.073.

MARTÍNEZ-CORDOVÁ, L.R., CAMPAÑATORRES, A., MARTÍNEZ-PORCHAS, M., LÓPEZ-ELÍAS, J.A. and GARCÍA-SIFUENTES, C.O. Effect of alternative mediums on production and proximate composition of the microalgae Chaetoceros muelleri as food in culture of the copepod Acartia sp. Latin American Journal of Aquatic Research, 2012, 40(1), 169-176. http://dx.doi.org/10.3856/ vol40-issue1-fulltext-16.

NUSCH, E.A. Comparison of different methods for chlorophyll and phaeopigments determination. Archiv für Hydrobiologie, 1980, 14(1), 4-36. http:// dx.doi.org/10.1127/archive-hydrobiol/14/1980/4.

ROCHA, O. and DUNCAN, A. The relationship between cell carbon and cell volume in freshwater algae species used in zooplankton studies. Journal of Plankton Research, 1985, 7(2), 279-294. http:// dx.doi.org/10.1093/plankt/7.2.279.

SHILTON, A.N., POWELL, N. and GUIEYSSE, B. Plant based phosphorus recovery from wastewater via algae and macrophytes. Current Opinion in Biotechnology, 2012, 23(6), 884-889. PMid:22889679. http://dx.doi.org/10.1016/j. copbio.2012.07.002.

SIPAÚBA-TAVARES, L.H. and ROCHA, O. Large-scale cultivation of plankton for feeding larvae and fish fry: I-Algae green. Biotemas, 1993, 6(1), 93-106. http:// dx.doi.org/10.5007/2175-7925.1993v6n1p93.
SIPAÚBA-TAVARES, L.H., IBARRA, L.C. and FIORESI, T.B. Ankistrodesmus gracilis (Reinsch) Korshikov (Chlorophyta) laboratory cultured in CHU12 and macrophyte with NPK media. Boletim do Instituto de Pesca, 2009, 35(1), 111-118. http:// dx.doi.org/10.5007/1678-2305.2009v35n1p111.

SIPAUBA-TAVARES, L.H., MILLAN, R.N., BERCHIELLI, F.D.A. and BRAGA, F.M.S. Use of alternative media and different types of recipients in a laboratory culture of Ankistrodesmus gracilis (Reinsch) Korshikov (Chlorophyceae). Acta Scientiarum Biological Sciences, 2011, 33(3), 247-253. http:// dx.doi.org/10.4025/actascibiolsci.v33i3.8046.

SONG, L., QIN, J.G., SU, S., XU, J., CLARKE, S. and SHAN, Y. Micronutrient requirements for growth and hydrocarbon production in the oil producing green algae Botryococcus braunii (Chlorophyta). PLoS One, 2012, 7(7), e41459. PMid:22848502. http:// dx.doi.org/10.1371/journal.pone.0041459.

STATSOFT, 2007. Statistica: Data Analysis Software System, version 8 [online]. [viewed 31 May 2016]. Available from: www.statsoft.com

TEW, K.S., CONROY, J.D. and CULVER, D.A. Effects of lowered inorganic phosphorus fertilization rates on pond production of perch fingerlings. Aquaculture, 2006, 255(1-4), 436-444. http://dx.doi. org/10.1016/j.aquaculture.2006.01.003.

USLU, L., ISIK, O., KOÇ, K. and GÖKSAN, T. The effects of nitrogen deficiencies on the lipid and protein contents of Spirulina platensis. African Journal of Biotechnology, 2011, 10(3), 386-389. http://dx.doi. org/10.5897/AJB10.1547.

VOLLENWEIDER, R.A. A manual on methods for measuring primary production in aquatic environments. 2nd ed. Oxford: Blackwell Scientific Publications, 1974, 225 p. IBP Handbook, vol. 12.

Received: 31 May 2016 Accepted: 31 March 2017 